\title{
UTILIZATION OF COAL BOTTOM ASH AS BRIQUETTE MATERIAL
}

\author{
Ninis Hadi Haryanti ${ }^{1 *}$, Suryajaya ${ }^{1}$, Henry Wardhana ${ }^{2}$, Rijali Noor ${ }^{3}$ \\ ${ }^{1}$ Program Studi Fisika FMIPA, Universitas Lambung Mangkurat, Banjarbaru, 70714, Indonesia \\ ${ }^{2}$ Program Studi Teknik Sipil FT, Universitas Lambung Mangkurat, Banjarbaru, 70714, Indonesia \\ ${ }^{3}$ Program Studi Teknik Lingkungan FT, Universitas Lambung Mangkurat, Banjarbaru, 70714, Indonesia \\ *Corresponding Author Email: ninishadiharyanti@gmail.com
}

Received: 29 June 2019

Revised: 14 December 2019

Accepted: 27 December 2019

Published: 31 December 2019

SPEKTRA: Jurnal Fisika dan Aplikasinya

p-ISSN: 2541-3384

e-ISSN: 2541-3392

\begin{abstract}
Research has been carried out on the use of coal bottom ash as a material for making briquettes as an alternative fuel. Carbonized of rubber seed shells and Halaban wood were used as mixtures and tapioca flour as adhesives. The composition used in making Halaban wood charcoal and coal bottom ash briquettes is $100 \%$ : $0 \%, 90 \%$ : $10 \%, 80 \%: 20 \%$, and $70 \%: 30 \%$. Tapioca flour used was as much as $5 \%$, the pressure of $150 \mathrm{~kg} / \mathrm{cm}^{2}$ and the size of 250 meshes. While for rubber seed shell and coal bottom ash briquettes, the composition used was with ratio $60 \%: 40 \%$ and $70 \%: 30 \%$, the pressure used was 100 , 150 , and $200 \mathrm{~kg} / \mathrm{cm}^{2}$ and the size of 50 meshes. Tapioca flour used was as much as $5 \%$. The results of the characterization of rubber seed shell and coal bottom ash briquettes were water content (4.35 10.65)\%, ash content (12.53 - 17.26)\%, and calorific value (3597.59 $4549.88) \mathrm{cal} / \mathrm{g}$. While the characterization results of Halaban wood charcoal and coal bottom ash briquettes were water content (2.947 4.097)\%, ash content $(0.383-26.667) \%$, and calorific value (47496621) $\mathrm{cal} / \mathrm{g}$. The results showed that if coal bottom ash in the composition were higher, it would increase the water content and ash content of the briquettes, while the calorific value would be lower. The recommended composition of coal bottom ash was about 10-20 $\%$. While if the briquettes pressure was higher, the water content, ash content and calorific value would be smaller. The recommended pressure was $150 \mathrm{~kg} / \mathrm{cm}^{2}$.
\end{abstract}

Keywords: coal bottom ash, briquettes, composition, rubber seed shells, halaban wood 


\section{INTRODUCTION}

Increasing energy demand causes an increase in fuel prices. One of the alternative energy is briquettes. Briquettes were chosen because they are cheap and environmentally friendly. Briquettes can be made from biomass and some wastes that are not utilized. Briquetting process is a process that is subjected to crushing, mixing of raw materials, molding and drying under certain conditions, so that briquettes that have a physical size, and certain chemical properties are obtained. Factors that influence the characteristics of briquettes are the density of charcoal powder, carbonization temperature, powder fineness, and pressure [1-4].

Biomass used as a briquettes material is expected to be more environmentally friendly because the biomass does not contain elements that are harmful to health and the environment, especially sulfur, as found in pure coal. With the increasing amount of biomass and coal ash wastes, it is necessary to innovate the use of these wastes as an alternative energy source, to provide added value from these wastes.

The rubber seed shell is one of the biomass that could be used as the primary material for making briquettes. South Kalimantan Province has 190 thousand hectares of rubber plantations, which would produce 162.5 thousand tons of rubber seed shell. It is estimated that each rubber tree could produce around 5,000 seeds/year/ha with a number of seeds of 200 seeds $/ \mathrm{kg}$ [5]. The rubber seed shell has a water content of $14.3 \%$, ash content of $0.1 \%$, fiber and various carbon compounds of $85.6 \%$ [6].

The waste of Halaban wood charcoal at PT. Citra Prima Utama Banjarbaru, South Kalimantan, is in the form of powder to the size of debris that is not utilized. The wastes are about 6 tons per day which are obtained from the quality selection process from wood charcoal to be exported. The wood charcoal industry itself is located in Ranggang Village, Pelaihari, Tanah Laut Regency, South Kalimantan Province. The types of wood used are Halaban, Ulin, Anglai, and mixed jungle wood [7]. The heating value of Halaban wood charcoal is about $6833.1 \mathrm{cal} / \mathrm{gr}$ [8].

In addition to rubber kernel shells and Halaban wood charcoal waste, one of the wastes that can be used as ingredients in briquetting is coal ash. Coal bottom ash is waste generated from burning coal at the Steam Power Plant. Research on coal bottom ash has been carried out. The containing compounds were $\mathrm{A}_{2} \mathrm{O}_{3}, \mathrm{CaO}, \mathrm{MgO}, \mathrm{MnO}_{2}, \mathrm{SiO}_{2}$ and $\mathrm{Fe}_{2} \mathrm{O}_{3}$ using sieve number 4, 8, 20, 60, 200 meshes [9]. Coal bottom ash still has a carbon content value that could be reused by increasing its heating value if mixed with biomass [10,11]. Coal bottom ash itself has a calorific value of $610 \mathrm{cal} / \mathrm{g}$, the water content of $2 \%$ and an ash content of $84 \%$ [12].

Research conducted by Haryanti, NH et al. [13] in the manufacture of briquettes using rubber seed shells and coal bottom ash with a mixture composition of $70 \%$ rubber seed shells and $30 \%$ coal bottom ash and varying the pressure, obtained water content, ash content and calorific value in the range of $4.35-9.43 \%, 12.53-12.94 \%$ and $3597.59-4549.88 \mathrm{cal} / \mathrm{g}$, respectively. Other research found that the water content, ash content and calorific value of Halaban wood charcoal waste were $4.22 \%, 41.93 \%$, and $6833.1 \mathrm{cal} / \mathrm{gr}$, respectively. While for coal bottom ash were $1.64 \%, 82.03 \%$ and $389.5 \mathrm{cal} / \mathrm{gr}$ [8]. 
Utilizing the waste of rubber seed shells, waste of Halaban wood charcoal and coal bottom ash in making briquette needs to be investigated to determine its characteristics. The problem in this study was how the characteristics of rubber seed shells and bottom ash briquettes and also Halaban wood charcoal and bottom ash briquettes. This study aims to obtain the characteristics of briquettes from rubber seed shell waste, Halaban wood charcoal waste, and coal ash waste, including their water content, ash content, and calorific value.

\section{METHOD}

The materials used are coal bottom ash from steam power plant Asam-Asam, Tanah Laut district, South Kalimantan; rubber seed shell from Pengaron Village, Banjar district; Halaban wood charcoal from PT. Citra Prima Utama Banjarbaru which its industrial location, is in Ranggang Pelaihari Village, Tanah Laut district, South Kalimantan; starch and water. The tools used were mortar, measuring cup, 50 and 250 meshes sieve, analytical balance, pulverizer, spatula, briquette maker, oven, furnace, hydraulic pump, crucible cup, desiccator, and bomb calorimeter.

This research is quantitative by utilizing coal bottom ash, rubber seed shell, and Halaban charcoal waste. This study is a continuation of previous research based on the briquette quality standard used, namely SNI 01-6235-2000, about the Quality of Wood Briquettes [14]. From previous studies, the results of the characteristics of coal bottom ash (water content, ash content, calorific value) and the elemental composition and morphology were obtained [8].

The composition of the mixture used in the manufacture of Halaban wood charcoal-coal bottom ash briquettes was in the ratio of $100 \%: 0 \%, 90 \%: 10 \%, 80 \%: 20 \%$, and $70 \%: 30 \%$. Tapioca flour used as much as $5 \%$, the pressure used was $150 \mathrm{~kg} / \mathrm{cm}^{2}$ and the particle size of 250 meshes. While rubber seed shell-coal bottom ash briquettes were in the ratio of $60 \%$ : $40 \%$ and $70 \%: 30 \%$. The pressure variations used were 100,150 , and $200\left(\mathrm{~kg} / \mathrm{cm}^{2}\right)$ and 50 meshes in size. While the tapioca flour adhesive used was $5 \%$.

The research began with a literature study and field sampling. Briquettes were made in the laboratory with varying coal bottom ash compositions, followed by briquettes characterizations. The factors that influence the characteristics of the briquettes are the density of charcoal powder, carbonization temperature, powder fineness, and pressure $(\mathrm{P})$. Therefore the coal ash used in the manufacture of briquettes was made in the form of a fine powder, which passes through a 50 and 250 meshes sieve. While the briquettes pressures used were 100,150 , and $200\left(\mathrm{~kg} / \mathrm{cm}^{2}\right)$.

\section{RESULT AND DISCUSSION}

Measurements conducted to determine the characteristics of briquettes were water content, ash content, and heating value. Measurements were carried out on variations in the composition of coal bottom ash. The starch adhesive was $5 \%$ of the total weight of the briquettes. There are two types of briquettes produced, namely: 1). Coal bottom ash- rubber seed shell briquettes, 2). Coal bottom ash-Halaban charcoal briquettes. 


\section{Water Content of Briquettes}

Water content is the amount of water contained in a briquette. Water content affects the value of the heat produced. Briquettes with high water content would make it difficult to ignite, cause smoke, and the heating value decreases.

\section{1) Rubber Seed Shell and Coal Bottom Ash Briquette}

The average value of water content in this study was $4.35 \%-10.65 \%$. Sample A was above the Indonesia national standard (SNI) for the maximum water content of $8 \%$. The lowest water content value of $4.35 \%$ in briquettes was yielded from the composition of $30 \%$ coal bottom ash and pressure of $200 \mathrm{~kg} / \mathrm{cm}^{2}$. At the pressure of $100 \mathrm{~kg} / \mathrm{cm}^{2}$ and $40 \%$, coal bottom ash composition produced high water content $(10.65 \%)$. While at the pressure of 150 and 200 $\mathrm{kg} / \mathrm{cm}^{2}$, the water content meets SNI. It could be concluded that higher pressure would give lower water content and vice versa. The results of the briquette water content measurements were shown in FIGURE 1.

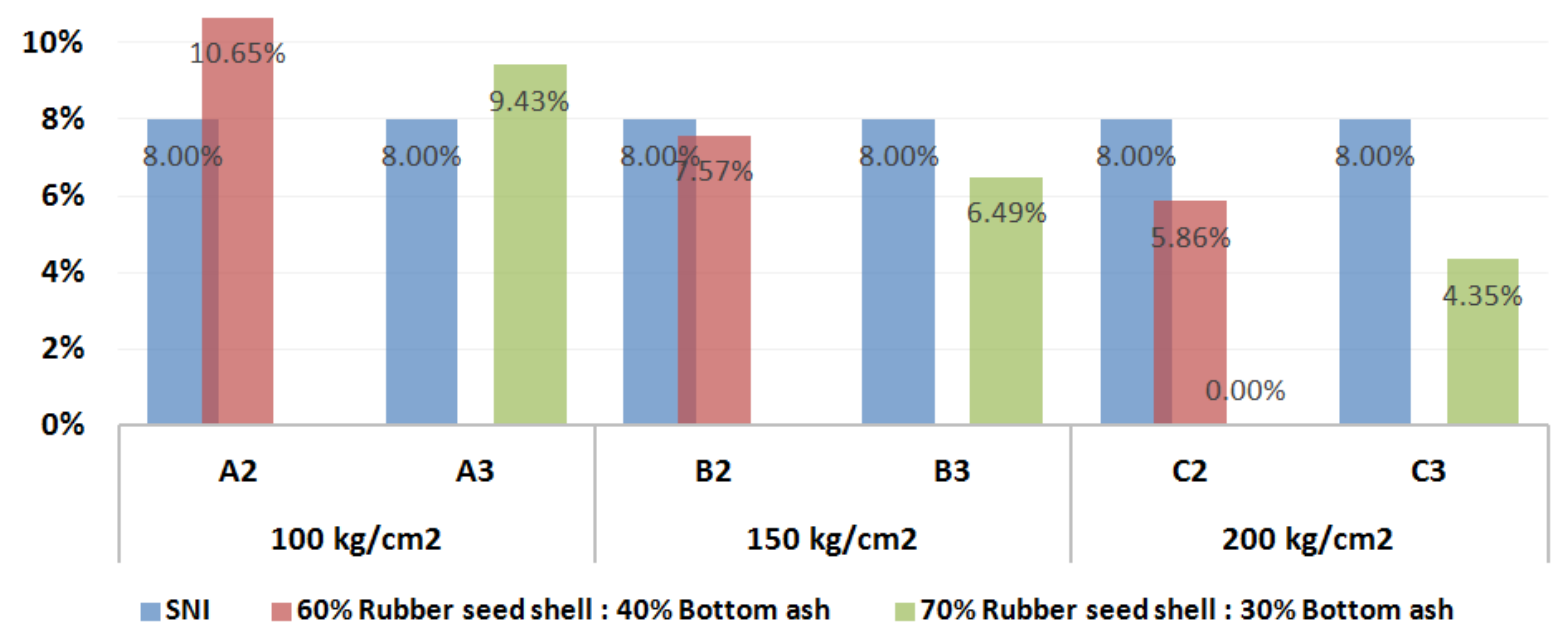

FIGURE 1. The water content of rubber seed shell and coal bottom ash briquettes.

From water content values, it can be seen that the higher composition of the biomass (rubber seed shell) used would reduce the water content. While higher coal bottom ash composition would increase the water content, this is in line with research conducted by Gunawan and Slamet [10]. In this study, the water content was ranged from $4.35 \%-10.56 \%$. The water content values in A2 and A3 samples were above the SNI specified; the water content in briquettes is a maximum of $8 \%$. From the results of water content measurements, it appeared that the water content decreases with increasing pressure applied. It is in line with research conducted by Darvina [15], stating that higher pressure gave lower water content. However, there were still samples whose water content was still above the quality standard, namely A2 and A3 samples with a pressure of $100 \mathrm{~kg} / \mathrm{cm}^{2}$. 


\section{2) Halaban Wood Charcoal and Coal Bottom Ash Briquette}

The results of the water content measurements conducted on Halaban wood charcoal and coal bottom ash briquettes are shown in FIGURE 2. The mean water content of the briquettes was $2.947-4.097 \%$. The average water content of all samples of Halaban wood charcoal and coal bottom ash briquette still meet the SNI standards, namely the Charcoal Briquette Quality Standards (SNI No. 01-6235-2000) for briquette, the water content is $\leq 8 \%$.

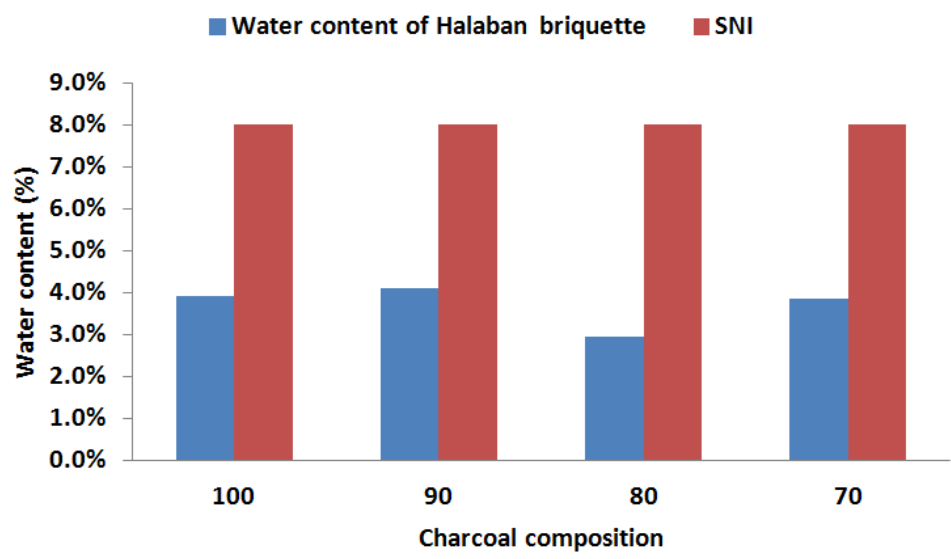

FIGURE 2. The water content of Halaban wood charcoal and coal bottom ash briquettes.

FIGURE 2 shows the average water content in briquettes with a mixture of Halaban wood charcoal and coal bottom ash in the ratio of $(100: 0) \%,(90: 10) \%,(80: 20) \%$ and $(70: 30) \%$. It can be seen that the water content in the briquettes was not stable. When viewed from the results of the preliminary test, the more the composition of the bottom ash used, the less water content obtained. This is thought to be due to the inhomogeneity of the mixing of the samples. Nevertheless, it can be concluded that the briquette water content produced fulfills SNI which is less than $8 \%$.

The resulting briquettes were as expected because they have a fairly low water content value. Water content would affect the briquette when it is to be burned. Higher water content makes the briquettes would be more difficult to be burned, and so the calorific value produced would also be lower.

\section{Ash Content of Briquettes}

Ash content is an inorganic substance that is left behind due to the complete burning of briquettes. The more ash content is obtained, the heating value of briquettes is smaller in value and this will cause the briquettes would be difficult to ignite. Ash content measurement aims to determine the amount of ash as residual combustion from briquettes. The ash content of briquettes is much influenced by the chemical composition of the briquettes themselves. One of the constituents of ash is silica. The high silica content in the bottom ash greatly influences the ash value in the briquettes. 


\section{1) Rubber Seed Shell and Coal Bottom Ash Briquette}

The average value of ash content produced was $12.53 \%-17.26 \%$. Research conducted by Gunawan [10] showed an increase in ash content when the composition of the bottom ash was increased as compared to the biomass used. It is due to the bottom ash has $83.93 \%$ of ash content while rubber shell charcoal has only $0.1 \%$. The maximum value of the SNI standard for ash content for briquettes is less than $8 \%$, then the value of ash content of briquettes produced was above the SNI standard. The high ash content produced is influenced by the material used in making briquettes. The results of briquette ash content are shown in FIGURE 3.

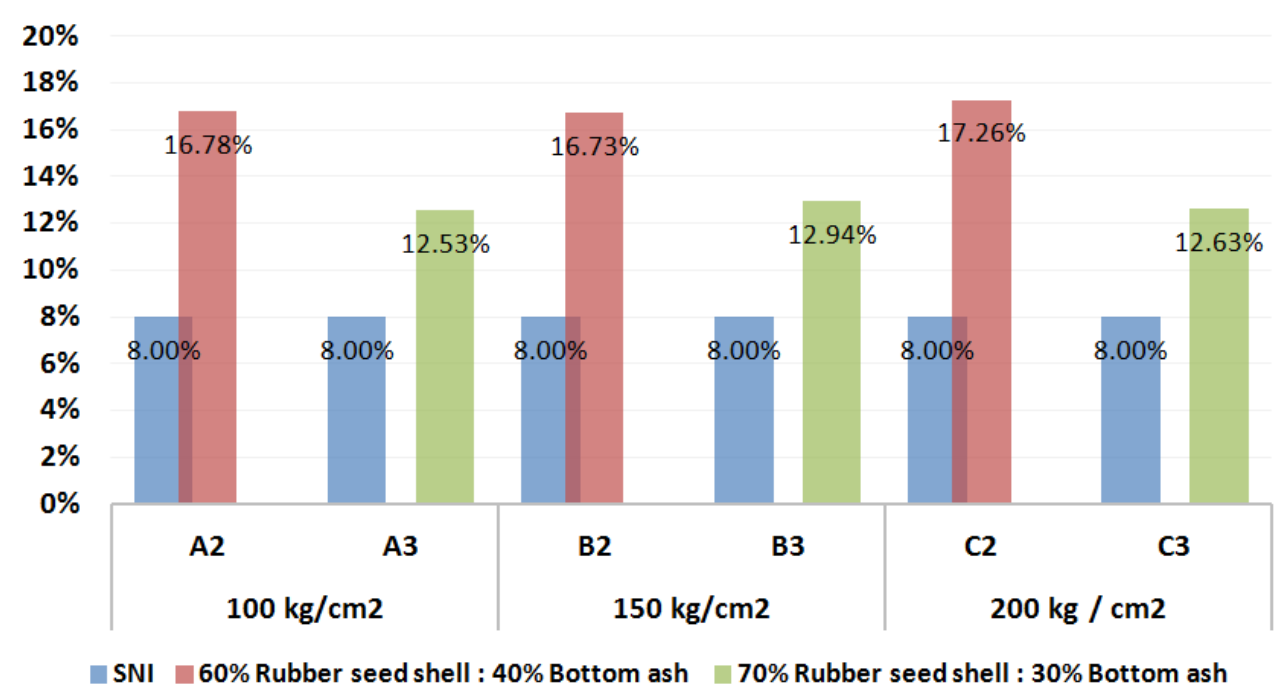

FIGURE 3. The ash content of rubber seed shell and coal bottom ash briquettes.

In the measurement of the ash content, it appeared that all samples have ash content values that are above the specified SNI, which ranges from $12.53 \%-17.26 \%$. SNI value for ash content is a maximum of $8 \%$. The constituent materials of briquettes strongly influence the high ash content. The increase in coal bottom ash composition would increase the percentage of ash content of briquettes produced; this is in line with Gunawan and Slamet's research [10].

The ash content of briquettes was still relatively low if compared to previous research conducted by Slamet and Gunawan [16], which was about biomass mixed briquettes (coffee shells, kapok shells, coconut shells) and bottom ash. The value of ash content obtained was ranged from $40.25 \%-62.12 \%$.

From the ash content values, it can be seen that higher pressure would decrease the ash content. It refers to Darvina's research [15], which states that ash levels would decrease if the pressure were increased. Referring to SNI 01-6235-2000, all samples were above the maximum value, but still relatively low when compared to the briquette mixture of bottom ash and other biomass. The high ash content is strongly influenced by the constituent materials from the raw material for making briquettes. 


\section{2) Halaban Wood Charcoal and Coal Bottom Ash Briquette}

The results of ash content measurements conducted on bio briquettes mixture of Halaban wood charcoal and coal bottom ash are shown in FIGURE 4. The mean ash content of bio briquettes was $0.383-26.667 \%$. The mean ash content in the $100 \%$ Halaban wood charcoal composition and $10 \%$ bottom ash mixture composition still meet the SNI standards, namely the Quality Standards for Wood Charcoal Briquettes (SNI No. 01-6235-2000) for briquette ash content is $\leq 8 \%$. Briquettes with a mixture of $20 \%$ and $30 \%$ bottom ash have the value of ash content that exceeds SNI quality standards.

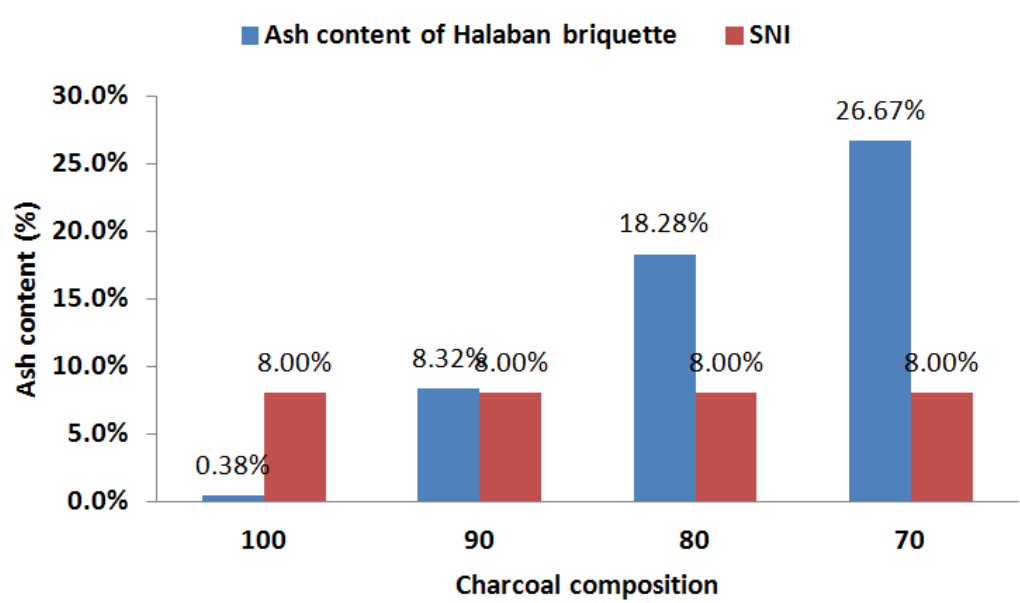

FIGURE 4. The ash content of Halaban wood charcoal and coal bottom ash briquettes.

FIGURE 4. shows the average ash content in briquettes with a mixture of wood charcoal and coal ash is (100: 0$) \%,(90: 10) \%,(80: 20) \%$, and $(70: 30) \%$. It can be seen the more the composition of the basic ash mixture used, the higher the ash content of the briquettes produced. It can be seen from the preliminary test results of ash content in the very high bottom ash, which is $82.07 \%$.

\section{Calorific Value of Briquette}

The calorific value is the amount of heat or heat that can be released by each kilogram of briquettes if wholly burned. It is essential to know the heating value to measure the energy content of each mass in the fuel.

\section{1) Rubber Seed Shell and Coal Bottom Ash Briquette}

From the investigation, the heating value was still below the SNI standard; the minimum heating value is $5000 \mathrm{cal} / \mathrm{g}$. The heating value of briquettes in this study was $3597.59-4549.88$ $\mathrm{cal} / \mathrm{g}$. The highest heating value of briquettes with sample code B with a pressure variation of $150 \mathrm{~kg} / \mathrm{cm}^{2}$ is equal to $4,578.32 \mathrm{cal} / \mathrm{g}$. When higher pressure was applied at $200 \mathrm{~kg} / \mathrm{cm}^{2}$, the heating value became lower. The calorific value which is quite low when compared to the SNI standard is assumed caused by bottom ash which has low calorific value. According to Astini [17], the calorific value in rubber seed shell briquettes was obtained in a high enough value 
which was $6370.9-6740.1 \mathrm{cal} / \mathrm{g}$. The addition of bottom ash makes the heating value of briquettes decrease [12,18]. If referring to the minimum value of briquette heat in the Regulation of Minister of Energy and Mineral Resources No. 047 the year 2006, the heat value produced has met the standard, namely the minimum heating value of 3,500 cal/g. The composition of $30 \%$ and $40 \%$ of coal bottom ash will produce briquettes with heating values that are not following SNI. The results of the briquette heating value are shown in FIGURE 5.

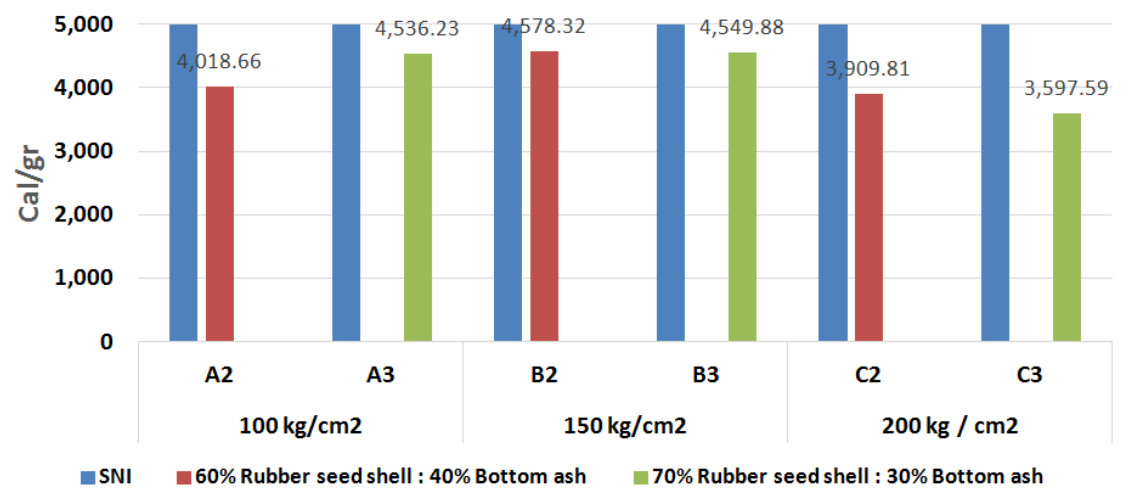

FIGURE 5. The calorific value of rubber seed shell - coal bottom ash briquettes.

In the measurement of heating value, the composition of the rubber seed shells affects the value of the heat produced; the rubber seed shell has a substantial heating value compared to the bottom ash, which has a heating value of $610 \mathrm{cal} / \mathrm{gram}$. The resulting heating value was at the ranges from 3597.59 - $4578.32 \mathrm{cal} / \mathrm{gr}$. This value was still below the specified SNI.

According to Anestiesia [12], the more biomass compositions used in the briquette mixture, the calorific value produced would be higher. According to Lestari [19], there is an indication of the influence of homogeneity of the mixing of the briquette mixture influencing the heating value produced, considering if the mixing of the briquette material is still done manually.

The heating value of briquettes produced is quite low when compared to SNI 01-6235-2000 on the Quality of Wood Briquettes, which is a minimum of 5,000 cal/gr. However, it is higher when compared to the briquette mixture of coconut shell and bottom ash biomass, which was equal to 4,214.59 - 4,500.66 cal/gr. According to Darvina [15], higher pressure applied would give higher heating value. However, this study found that heating value varies. It is assumed that the homogeneity factor when mixing the briquette material was not mixed evenly [19].

\section{2) Halaban Wood Charcoal and Coal Bottom Ash Briquette}

The results of the heating value measurement conducted on a mixture of Halaban wood charcoal and coal bottom ash briquettes are shown in FIGURE 8. The mean heating value of briquettes was $4749.600-6621.067 \mathrm{cal} / \mathrm{g}$. The average heating values of all samples of Halaban wood charcoal and coal bottom ash briquettes meet SNI standards for Wood Charcoal Briquette Quality Standards (SNI No. 01-6235-2000) for the heating value of briquettes which is $\leq 5000 \mathrm{cal} / \mathrm{g}$. 


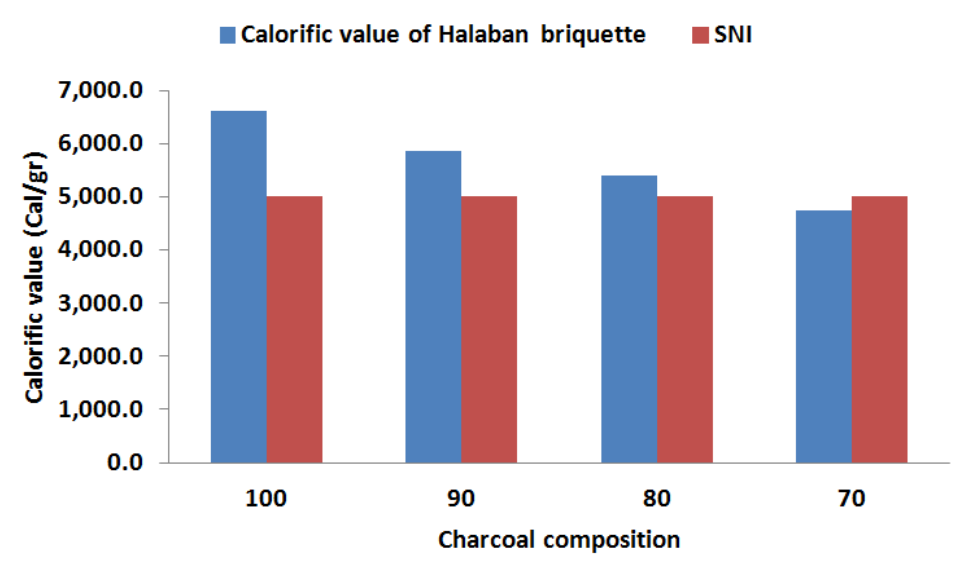

FIGURE 6. The calorific value of Halaban wood charcoal and coal bottom ash briquettes.

FIGURE 6. shows the heating value of briquettes with a mixture composition of $(100: 0) \%$, (90:10)\%, (80:20)\%, and (70:30)\%. The more Halaban wood charcoal composition used, higher the heating value of briquettes would be generated. From the preliminary study, the heating value of Halaban wood charcoal was $6,833.133 \mathrm{cal} / \mathrm{g}$. In contrast, it can be seen that the more of the bottom ash composition used, the calorific value obtained was getting smaller. From the preliminary study, the calorific value of bottom ash was only $389.5 \mathrm{cal} / \mathrm{g}$. From FIGURE 6, it can be seen that the Halaban wood charcoal and coal bottom ash briquettes with variations in the composition of (70:30)\% do not meet the SNI standard requirements because the calorific value obtained was less than $5,000 \mathrm{cal} / \mathrm{g}$.

Based on the measurements of water content, ash content, and the heating value of the briquettes, the recommended composition of the coal bottom ash mixture was $10 \%$ to $20 \%$ to produce briquettes that meet SNI while the pressure was 100 to $150 \mathrm{~kg} / \mathrm{cm}^{2}$.

\section{CONCLUSION}

Briquettes from rubber seed shell, Halaban wood charcoal, and coal bottom ash could be used as alternative energy sources. The proximate analysis of rubber seed shell - coal bottom ash briquettes such as water content, ash content and calorific value were 4.35 - $10.65 \% ; 12.53$ $17.26 \%$ and $3597.59-4549.88 \mathrm{cal} / \mathrm{g}$, respectively. While the proximate analysis of Halaban wood charcoal - coal bottom ash briquettes were 2.947 - $4.097 \%$; 0.383 - $26.667 \%$ and 4749 - $6621 \mathrm{cal} / \mathrm{g}$. Not all the characteristics of briquettes in this study meet SNI standards.

The more composition of the coal bottom ash mixture used will increase the water content and ash content of the briquettes produced, while the calorific value obtained would be lower. The recommended composition of coal bottom ash mixture was $10-20 \%$. The results showed that higher pressure would make the water content, ash content and heating value became lower. The recommended pressure was $150 \mathrm{~kg} / \mathrm{cm}^{2}$. The advice that can be given is that it needs further research with a composition of different material mixtures with variations in mesh sizes and pressure. 


\section{ACKNOWLEDGMENT}

We acknowledge to all those who have helped in this initial research, especially to the Institute of Research and Community Service at the University of Lambung Mangkurat, who have provided funding through The Primary Higher Education Basic Research.

\section{REFERENCES}

[1] A.P.T. Jupar, “"Analisa Pengaruh Metode Torefaksi Terhadap Kenaikan Nilai Kalor Biobriket Campuran 75\% Kulit Mete dan 25\% Sekam Padi dengan Persentase Berat", Skripsi, Universitas Diponegoro, Semarang, 2013.

[2] J. E. Purba, "Pengaruh Variasi Tekanan Kempa dan Konsentrasi Perekat Terhadap Sifat Fisika-Kimia Briket Arang dari Limbah Tandan Kosong Kelapa Sawit”, Skripsi Universitas Gadjah Mada, Yogyakarta, 2011.

[3] A. Nugraha, A. Widodi \& S. Wahyudi, "Pengaruh Tekanan Pembriketan dan Persentase Briket Campuran Gambut dan Arang Pelepah Daun Kelapa Sawit Terhadap Karakteristik Pembakaran Briket”, Jurnal Rekayasa Mesin, vol. 8 : 29 - 36, 2017.

[4] R. Setyowati \& M. Tirono, "Pengaruh Variasi Tekanan Pengepresan dan Komposisi Bahan Terhadap Sifat Fisis Briket Arang”, Jurnal Neutrino, pp 23-24. 7, 2014.

[5] BPS, 2015.

[6] Selpiana, et al., "Pengaruh Temperatur dan Komposisi pada Pembuatan Briket dari Cangkang Biji Karet dan Plastik Polietilen" Seminar Nasional Added Value of Energy Resources (AVoER) Ke-6, Palembang, 2014.

[7] M. F. Mahdie, "Briket Arang dari Limbah Arang PT.Citra Prima Banjarbaru”, Jurnal Hutan Tropis, vol. $10: 1-8,2010$.

[8] N. H. Haryanti, Suryajaya, H. Wardhana, Y. Anggraini \& N. S. Andini, "Karakterisasi arang kayu alaban (vitex pubescens vahl), abu dasar dan abu terbang batubara sebagai material campuran briket", Prosiding UNNES Physics International Symposium in conjunction with $32^{\text {nd }}$ National Seminar on Physics - Physical Society of Indonesia, Semarang 3 Mei 2018.

[9] H. Wardhana \& Ninis H Haryanti, "Studi Abu Dasar Batubara Sebagai Bahan Konstruksi Campuran Beton”, Jurnal Info-Teknik, pp 39-41, Vol. 2 No.1, 2001.

[10] B. Gunawan \& S. Slamet, "Pembuatan Briket dari Limbah Bottom ash PLTU dengan Biomassa Cangkang Kopi”, Jurnal SIMETRIS, Vol 6 No 2, 2015.

[11] Gunawan, et al., "Pengujian Nilai Kalor Dan Kadar Air Terhadap Briket Sebagai Bahan Bakar Padat yang Terbuat dari Bottom ash Limbah PLTU Dengan Biomassa Tempurung Kelapa melalui Proses Karbonisasi”, Prosiding SNST Ke-6 Tahun 2015 Fakultas Teknik Universitas Wahid Hasyim Semarang, 2015.

[12] S. E. Anetiesia, Syafrudin, B. Zaman, "Pembuatan Briket dari Bottom Ash dan Arang Tempurung Kelapa Sebagai Sumber Energi Alternatif”, Jurnal Teknik Lingkungan, Vol. 4 No. 1, 2015.

[13] N. H. Haryanti, R. Noor, \& D. Aprilia, "Karakterisasi dan Uji Emisi Briket Campuran Cangkang Biji Karet dan Abu Dasar Batubara", Prosiding Pendidikan Fisika FKIP, Universitas Lambung Mangkurat, Banjarbaru, 2018. 
[14] Standar Nasional Indonesia (SNI) No. 01 - 6235 - 2000.

[15] Y. Darvina \& N. Asma, "Upaya Peningkatan Kualitas Briket dari Arang Cangkang dan Tandan Kosong Kelapa Sawit (TKKS) melalui Variasi Tekanan Pengpresan”, Laporan Penelitian Dana Jurusan Fakultas Matematika dan IPA Jurusan Fisika Universitas Negeri Padang, Padang, 2011.

[16] S. Slamet \& B. Gunawan, "Briket Campuran Bottom ash Batu Bara Limbah PLTU dan Biomassa melalui Proses Karbonisasi sebagai Sumber Energi Alternatif Terbarukan", Prosiding SNATIF Ke-3 Tahun 2016, ISBN: 978-602-1180-33-4, 2016.

[17] N. Astini, "Pemanfaatan Limbah Cangkang Biji Karet (Hevea Brasiliansis Muell.Arg) sebagai Briket Arang", Fakultas Teknik Universitas Lambung Mangkurat. Banjarbaru, 2014.

[18] N. H. Haryanti, S. Suryajaya, H. Wardhana, S. Husain, Y. Anggraini \& N. Sofi, Briquette From Halaban Charcoal And Coal Combustion Ashes. The $8^{\text {th }}$ ICTAP (International Conference on Theoretical and Applied Physics) \& SFN (Simposium Fisika Nasional) XXXI. Medan 20-21 September 2018.

[19] L. Lestari, E. S. Hasan \& R. Risna, "Pengaruh Tekanan Dan Ukuran Partikel Terhadap Kualitas Briket Cangkang Coklat", Jurnal Aplikasi Fisika, Universitas Halu Oleo, Kendari, Vol. 13 No. 2, 2017. 
